\title{
UPAYA PENINGKATAN AKTIVITAS SISWA PADA MATA PELAJARAN IPA MELALUI MODEL PEMBELAJARAN KOOPERATIF TIPE STAD DI KELAS III-B SD NEGERI NO. 053975 STABAT LAMA
}

\author{
Arniah \\ Guru SD Negeri No. 053975 Stabat Lama \\ Surel : arniah_s.pd@yahoo.com
}

\begin{abstract}
Improving Student Learning Lesson In IPA With Cooperative Learning Tipe STAD (Student Team Achievement Division) In Class III-B SD Negeri No. 053975 Stabat Lama T.A 2015/2016. This research aims to improve students' learning activities using Student Team Achievement Division learning model in class III-B SD Negeri No 053975 Stabat Lama. These research subjects are 30 students. The study lasted for two cycles can be concluded that 1) Activities of student learning through the implementation of the Student Team Achievement Division learning model is based on observations of the two observers increased from the first cycle to the second cycle. 2) The results of student learning through the implementation of the Student Team Achievement Division learning model increases from the first cycle to the second cycle.
\end{abstract}

Keywords: Learning Student Team Achievement Division, Student Activities

\begin{abstract}
Abstrak : Upaya Peningkatan Aktivitas Belajar Siswa Pada Mata Pelajaran IPA Melalui Model Pembelajaran Kooperatif Tipe STAD (Student Team Achievement Division) Di Kelas III-B SD Negeri No. 053975 Stabat Lama 2015/2016. Penelitian ini bertujuan untuk meningkatkan aktivitas belajar siswa dengan menggunakan model pembelajaran Student Team Achievement Division di kelas III-B SD Negeri No 053975 Stabat Lama. Subjek penelitian ini berjumlah 30 orang siswa. Penelitian berlangsung selama dua siklus dapat disimpulkan bahwa 1) Aktivitas belajar siswa melalui penerapan model pembelajaran Student Team Achievement Division berdasarkan pengamatan kedua pengamat mengalami peningkatan dari siklus I ke siklus II. 2) Hasil belajar siswa melalui penerapan model pembelajaran Student Team Achievement Division meningkat dari siklus I ke siklus II.
\end{abstract}

Kata kunci : Model Pembelajaran Kooperatif Tipe STAD, Aktivitas Siswa

\section{PENDAHULUAN}

Upaya melaksanakan pembelajaran yang berorientasi pada aktivitas siswa terus dilakukan peneliti sebagai guru IPA di SD Negeri No. 053975 Stabat Lama. Beberapa varian model pembelajaran kooperatif telah diterapkan. Bahkan sekolah telah menjadikan pembelajaran kooperatif sebagai pokok model pembelajaran yang diterapkan dalam kelas, untuk menyikapi perubahan paradigma ke arah pembelajaran berpusat pada siswa. Namun kendala yang harus dihadapi guru dalam menerapkan model pembelajaran kooperatif terus bermunculan. Pembelajaran koperatif yang diterapkan guru seringkali memunculkan berbagai sikap negatif.

Jika kerja kelompok tidak berhasil, siswa cenderung saling menyalahkan. Sebaliknya jika berhasil, muncul perasaan tidak adil. Siswa yang pandai/rajin merasa rekannya yang kurang mampu telah membonceng pada hasil kerja mereka. Semangat siswa dalam mengembangkan diri secara individual bisa terancam karena siswa bukannya belajar secara maksimal, melainkan belajar mendominasi ataupun melempar tanggung jawab. Akhirnya 
pembelajaran seperti ini berujung pada munculnya keributan di dalam kelas. Muncul pemikiran guru yang keliru bahwa melaksanakan pembelajaran kooperatif menyulitkan pengendalian kelas dan menyusahkan.

Pemikiran semacam ini mengakibatkan guru lebih memilih menerapkan pembelajaran konvensional/ceramah yang berlangsung satu arah karena dianggap lebih mudah dan menjamin siswa lebih terkendali dalam pembelajaran. Padahal hasil yang diperoleh sama buruknya, aktivitas belajar siswa tidak tergarap dengan baik. Dampaknya adalah minat dan hasil belajar siswa berupa penguasaan konsep IPA Terpadu siswa tidak tercapai. Apalagi dampak pengiring pembelajaran IPA berupa keterampilan berpikir masih jauh dari harapan.

Mengupayakan pembelajaran berorientasi aktivitas ternyata bukan sesuatu yang mudah karena telah lama pembelajaran IPA di SD Negeri No. 053975 Stabat Lama berlangsung lebih mengedepankan ketercapaian materi dari pada kompetensi. Akibatnya pembelajaran selalu mengandalkan penyampaian materi melalui metode ceramah. Pembelajaran yang berlangsung dengan alur yang sama terus menerus, tidak ada variasi apalagi siswa tidak terlibat secara aktif membuat siswa menurun aktivitas belajarnya.

Berdasarkan pengalaman mengajar sejak tahun 1987 sampai sekarang masalah yang dihadapi dalam mengajarkan mata pelajaran IPA adalah kurangnya minat belajar, siswa sering ribut didalam kelas dan nilai siswa yang masih rendah khususnya kelas III-B. Masalah tersebut disebabkan karena metode yang digunakan, adalah ceramah dan juga guru tidak memiliki media untuk mengajar.
Untuk

meminimalkan permasalahan tersebut maka guru harus menggunakan metode pembelajaran yang dapat menciptakan suasana belajar yang melibatkan siswa bekerja secara gotong royong yaitu dengan menggunakan model pembelajaran kooperatif. Salah satu model pembelajaran yang dapat diterapkan adalah model pembelajaran kooperatif tipe Student Teams Achievement Division (STAD). Dalam metode STAD siswa dikelompokkan dalam tipe belajar yang beranggotakan 4-5 oarang yang merupakan campuran menurut tingkat prestasi, jenis kelamin, dan suku. Anggota dalam kelompok saling belajar dan membelajarkan. Fokus yang ditekankan adalah bahwa keberhasilan seorang anggota kelompok akan berpengaruh terhadap keberhasilan kelompoknya. Dengan demikian pula keberhasilan kelompok akan berpengaruh terhadap keberhasilan individu siswa.

Berdasarkan latar belakang di atas, maka dapat dirumuskan suatu masalah sebagai berikut; 1) Bagaimana aktivitas belajar siswa setelah diterapkannya model pembelajaran kooperatif tipe STAD pada mata pelajaran IPA di kelas III-B semester genap SD Negeri No. 053975 Stabat Lama T.A. 2015/2016?; 2) Bagaimana hasil belajar siswa meningkat dengan diterapkannya model pembelajaran kooperatif tipe STAD pada mata pelajaran IPA di kelas III-B semester genap SD Negeri No. 053975 Stabat Lama T.A. 2015/2016?

Sesuai dengan permasalahan di atas, penelitian ini bertujuan untuk; 1) Untuk mengetahui penigkatakan aktivitas belajar siswa dengan diterapkannya model pembelajaran kooperatif tipe STAD pada mata 
pelajaran IPA di kelas III-B semester genap SD Negeri No. 053975 Stabat Lama T.A. 2015/2016; 2). Untuk mengetahui peningkatan hasil belajar siswa dengan diterapkannya model pembelajaran kooperatif tipe STAD pada mata pelajaran IPA di kelas III-B semester genap SD Negeri No. 053975 Stabat Lama T.A. 2015/2016.

Menurut pengertian psikologis, belajar merupakan suatu proses perubahan yaitu perubahan tingkah laku sebagai hasil dari interaksi dengan lingkungannya dalam memenuhi kebutuhan hidupnya. Slameto (2003:2) menyatakan bahwa : "Belajar ialah suatu proses usaha yang dilakukan seseorang untuk memperoleh suatu perubahan tingkah laku secara keseluruhan, sebagai hasil pengalamannya sendiri dalam interaksi dengan lingkungannya".

Hasil belajar merupakan proses terjadinya perubahan tingkah laku pada diri siswa yang dapat diamati dan diukur dalam bentuk perubahan pengetahuan, sikap dan keterampilan. Menurut Bloom (Dalam Sudjana, 2005), Dalam setiap kegiatan, manusia selalu mengharapkan hasil. Begitu pula dengan kegiatan belajar. Pada umumnya hasil belajar dan tingkah laku penguasaan materi pelajaran diukur dengan penelitian.

Model pembelajaran akan dibahas dalam beberapa bagian, yakni pembelajaran kooperatif, unsur-unsur pembelajaran kooperatif, perbedaan pembelajaran kooperatif dengan pembelajaran tradisional/ceramah dan pentingnya pembelajaran kooperatif.

\section{METODE}

Tempat penelitian adalah tempat yang digunakan dalam melakukan penelitian untuk memperoleh data yang diinginkan. Penelitian ini dilakukan di SD Negeri No. 053975 Stabat Lama yang bertempat di Jalan Kedondong Timur Desa Stabat Lama Barat.

Waktu penelitian adalah waktu berlangsungnya penelitian atau saat penelitian ini dilangsungkan. Penelitian ini dilaksanakan pada semester genap Tahun Ajaran 2015/2016 selama empat bulan mulai dari bulan Februari 2016 sampai dengan Juni 2016. Pengambilan data dilaksanakan pada bulan April selama 4 (empat) KBM yang dibagi dalam 2 (dua) siklus dengan pokok bahasan energi dan gerak benda.

Subyek penelitian adalah siswasiswi kelas III-B SD Negeri No. 053975 Stabat Lama Tahun Ajaran 2015/2016 yang berjumlah 30 orang siswa.

Alat pengumpul data dalam penelitian ini adalah; 1) tes hasil belajar; 2) lembar observasi aktivitas siswa;

Penelitian ini menggunakan Penelitian Tindakan Kelas (PTK). PTK adalah suatu bentuk kajian yang bersifat reflektif oleh pelaku tindakan yang dilakukan untuk meningkatkan kemantapan rasional dari tindakan mereka dalam melaksanakan tugas, memperdalam pemahaman terhadap tindakan-tindakan yang dilakukan itu, serta memperbaiki kondisi dimana praktek pembelajaran tersebut dilakukan.

Sesuai dengan jenis penelitian yang dipilih, yaitu penelitian tindakan kelas, maka penelitian ini menggunakan model penelitian tindakan dari Kemmis dan Taggart (dalam Sani dan Sudiran, 2012), yaitu berbentuk spiral dari siklus yang satu ke siklus yang berikutnya. Setiap siklus meliputi planning (rencana), action (tindakan), observation (pengamatan), dan reflection (refleksi). Langkah pada siklus berikutnya adalah perencanaan yang sudah direvisi, tindakan, pengamatan, dan refleksi. 
Metode Analisis Data pada penelitian ini digunakan metode deskriptif dengan membandingkan hasil belajar siswa sebelum tindakan dengan hasil belajar siswa setelah tindakan.

Langkah-langkah pengolahan data sebagai berikut:

1. Merekapitulasi nilai pretes sebelum tindakan dan nilai tes akhir Siklus I dan Siklus II

2. Menghitung nilai rerata atau persentase hasil belajar siswa sebelum dilakukan tindakan dengan hasil belajar setelah dilakukan tindakan pada Siklus I dan Siklus II untuk mengetahui adanya peningkatan hasil belajar.

Penelitian ini dianggap berhasil apabila tercapai tujuan penelitian berupa tercapainya hasil belajar IPA siswa. Dengan ketentuan yang ditetapkan untuk keberhasilan penelitian adalah penelitian dianggap berhasil apabila ketuntasan belajar siswa berupa hasil belajar IPA siswa diperoleh $85 \%$ siswa dalam kelas dengan perolehan nilai mencapai KKM sebesar 70

\section{PEMBAHASAN}

Data penelitian yang diperoleh berupa data observasi pengamatan aktivitas siswa dalam model kooperatif tipe STAD dan data tes hasil belajar siswa pada setiap siklus. Data lembar observasi digunakan untuk mengetahui penerapan model pembelajaran kooperatif tipe STAD dalam memperbaiki aktivitas belajar siswa.

Data tes hasil belajar untuk mengetahui peningkatan ketuntasan belajar siswa setelah diterapkan proses belajar mengajar dengan menerapkan model kooperatif tipe STAD. Sebelum dilakukan KMB siklus I dilakukan tes hasil belajar sebagai tes kemampuan awal siswa. Merujuk pada lampiran data pretes diperoleh nilai terendah siswa 40, sedangkan nilai tertingginya 60 . Dengan rata-rata 47,3, sedangkan KKM adalah 70. Tidak ada siswa yang memperoleh nilai tuntas atau ketuntasan klasikal $0 \%$. Dapat dipahami karena memang siswa belum diajarkan materi ini, akan tetapi rendahnya kemampuan awal menggambarkan bahwa siswa malas membaca dari rumah sebelum belajar di sekolah

Observasi menghasilkan data aktivitas belajar siswa yang belum begitu menunjukkan siswa aktif diskusi. Data hasil observasi aktivitas belajar siswa disajikan dalam Tabel.

Tabel Skor Aktivitas Belajar Siswa Siklus I

\begin{tabular}{|c|l|c|c|}
\hline No & \multicolumn{1}{|c|}{ Aktivitas } & Skor & Proporsi \\
\hline 1 & $\begin{array}{l}\text { Menulis, } \\
\text { membaca }\end{array}$ & 25.5 & $51 \%$ \\
\hline 2 & $\begin{array}{l}\text { Mengerjakan } \\
\text { LKS }\end{array}$ & 10.25 & $21 \%$ \\
\hline 3 & $\begin{array}{l}\text { Bertanya pada } \\
\text { teman }\end{array}$ & 1.5 & $3 \%$ \\
\hline 4 & $\begin{array}{l}\text { Bertanya pada } \\
\text { guru }\end{array}$ & 2.5 & $5 \%$ \\
\hline 5 & $\begin{array}{l}\text { Yang tidak } \\
\text { relevan }\end{array}$ & 10.25 & $21 \%$ \\
\hline \multicolumn{2}{|c|}{ Jumlah } & 50 & $100 \%$ \\
\hline
\end{tabular}

Merujuk pada Tabel aktivitas dominan yang dilakukan siswa adalah menulis dan membaca (51\%) kondisi ini belum sesuai dengan yang diharapkan karena seharusnya aktivitas diskusi lebih dominan ketimbang aktivitas individual tersebut, sementara aktivitasi mengerjakan LKS dalam posisi kedua (21\%), bertanya pada guru (5\%) atau siswa masih sangat bergantung pada guru. Dan aktivitas bertanya pada teman dan yang tidak relevan berturut-turut (3\%) dan (21\%).

Pada akhir proses belajar mengajar siswa diberi tes Formatif I 
dengan tujuan untuk mengetahui tingkat keberhasilan siswa dalam proses belajar mengajar yang telah dilakukan. Adapun data hasil formatif pada Siklus I ditunjukkan Tabel.

Tabel Distribusi Hasil Formatif 1

\begin{tabular}{|c|c|c|}
\hline Nilai & Frekunsi & Rata-rata \\
\hline 60 & 15 & \multirow{2}{*}{73.3} \\
\cline { 1 - 2 } 80 & 10 & \\
\cline { 1 - 2 } 100 & 5 & \\
\cline { 1 - 2 } Jumlah & 30 & \\
\hline
\end{tabular}

Merujuk pada Tabel tersebut, nilai terendah formatif I adalah 60 dan tertinggi adalah 100. Merujuk pada KKM sebesar 70 maka hanya 15 dari 30 orang siswa mendapat nilai ketuntasan atau ketuntasan klasikal tercapai sebesar $50 \%$. Nilai ini berada di bawah kriteria ketuntasan klasikal sebesar $85 \%$ sehingga dapat dikatakan KBM siklus I gagal memberi ketuntasan belajar dalam kelas. Nilai rata-rata kelas adalah 73,3 yang masih berada di bawah KKM pembelajaran IPA yaitu 70

Dalam pelaksanaan kegiatan belajar mengajar diperoleh informasi dari hasil pengamatan sebagai berikut:

a. Dari gambaran pembelajaran, guru sudah menjelaskan materi pembelajaran tetapi belum memberikan contoh-contoh yang mempermudah siswa.

b. Guru juga meninggikan suara saat siswa bertanya hal-hal yang tidak terlalu penting sehingga siswa menjadi takut memberikan tanggapan pada langkah berikutnya sehingga siswa terkesan pasif.

c. Beberapa siswa kurang aktif apabila guru menyuruh menyelesaikan soal LKS.

d. Siswa yang bertanya didominasi oleh siswa yang pandai dalam menyelesaikan masalah. e. LKS dikerjakan kurang optimal karena guru tidak memberitahukan kepada siswa pada pertemuan sebelumnya bahwa akan diberikan LKS pada setiap pertemuan.

f. Siswa belum memahami penjelasan guru, sehingga guru dan peneliti harus berkeliling untuk mengetahui pemahaman siswa.

g. Ketika mengerjakan latihan soal, masih ada siswa yang berbicara dengan temannya.

h. Dalam menjelaskan materi pelajaran guru belum menggunakan media pembelajaran dan alat peraga, sehingga siswa sulit memahami ketika guru mengajar.

Observasi yang dilakukan dua guru sejawat menghasilkan data aktivitas belajar siswa Siklus II yang mengalami perbaikan dibandingkan Siklus sebelumnya. Data hasil observasi aktivitas belajar siswa disajikan dalam Tabel.

Tabel Skor Aktivitas Belajar Siswa Siklus II

\begin{tabular}{|c|c|c|c|}
\hline No & Aktivitas & Skor & Proporsi \\
\hline 1 & $\begin{array}{l}\text { Menulis, } \\
\text { membaca }\end{array}$ & 14.25 & $29 \%$ \\
\hline 2 & $\begin{array}{l}\text { Mengerjakan } \\
\text { LKS }\end{array}$ & 20.75 & $42 \%$ \\
\hline 3 & $\begin{array}{l}\text { Bertanya pada } \\
\text { teman }\end{array}$ & 8 & $16 \%$ \\
\hline 4 & $\begin{array}{l}\text { Bertanya pada } \\
\text { guru }\end{array}$ & 5.75 & $12 \%$ \\
\hline 5 & $\begin{array}{l}\text { Yang tidak } \\
\text { relevan }\end{array}$ & 1.25 & $3 \%$ \\
\hline & Jumlah & 50 & $100 \%$ \\
\hline
\end{tabular}

Merujuk pada Tabel aktivitas dominan yang dilakukan siswa adalah mengerjakan LKS (42\%) kondisi ini telah sesuai dengan yang diharapkan karena seharusnya aktivitas kerja memang lebih dominan ketimbang aktivitas individual menulis dan 
membaca yang berada pada peringkat kedua (29\%), bertanya pada guru turun menjadi (12\%) atau siswa mulai mandiri. Hal ini diperkuat dengan aktivitas bertanya pada teman dan yang tidak relevan berturut-turut (16\%) dan (4\%).

Pada akhir proses belajar mengajar Siklus II siswa diberi tes Formatif II dengan tujuan untuk mengetahui tingkat keberhasilan siswa dalam proses belajar mengajar yang telah dilakukan. Adapun data hasil formatif pada Siklus II ditunjukkan Tabel.

Tabel Distribusi Hasil Formatif II

\begin{tabular}{|c|c|c|}
\hline Nilai & Frekunsi & Rata-rata \\
\hline 60 & 3 & \multirow{2}{*}{84} \\
\cline { 1 - 2 } 80 & 18 & \\
\cline { 1 - 2 } 100 & 9 & \\
\cline { 1 - 2 } Jumlah & 30 & \\
\cline { 1 - 2 }
\end{tabular}

Merujuk pada Tabel. nilai terendah formatif II adalah 60 dan tertinggi adalah 100. Merujuk pada KKM sebesar 70 maka 27 dari 30 siswa mendapat nilai ketuntasan atau ketuntasan klasikal tercapai sebesar $90 \%$. Nilai ini berada pada kriteria ketuntasan klasikal sebesar 85\% sehingga dapat dikatakan KBM siklus II berhasil memberi ketuntasan belajar dalam kelas. Nilai rata-rata kelas adalah 84 sudah di atas KKM. Dengan demikian karena keterbatasan waktu dan biaya dalam penelitian maka penelitian dicukupkan dalam dua siklus

Beberapa hal yang dapat dicatat dalam refleksi pembelajaran siklus II adalah sebagai berikut:

a) Siswa mulai aktif dalam diskusi dengan ditunjukkan oleh hasil observasi aktivitas belajarnya yang sedikit lebih baik dari pada siklus I. b) Ketuntasan hasil belajar siswa meningkat dari $50 \%$ menjadi $90 \%$ atau dalam ketegori berhasil. Hal ini tidak terlepas dari rencan perbaikan yang dilakukan di akhir siklus I yang berujung kepada meningkatnya hasil belajar siswa.

c) Siswa mulai terbiasa mengungkapkan pendapatnya terlihat dari dokumentasi penelitian dan aktivitas belajar siswa dimana aktivitas diskusi meningkat dan mencapai dominan, berarti menggunakan media cukup membantu dalam memicu kemampuan siswa.

Peningkatan kualitas aktivitas belajar ditunjukkan dengan perubahan aktivitas siklus I ke siklus II. Rata-rata aktivitas menulis dan membaca mengalami perubahan dari proporsi $51 \%$ menjadi 29\%. Aktivitas mengerjakan dalam diskusi naik dari $21 \%$ menjadi $42 \%$. Aktivitas bertanya pada teman naik dari $3 \%$ menjadi $16 \%$. Aktivitas bertanya kepada guru meningkat dari $5 \%$ menjadi $12 \%$. Aktivitas yang tidak relevan dengan $\mathrm{KBM}$ turun dari $21 \%$ menjadi $3 \%$.

Nilai-nilai ini menunjukkan bahwa aktivitas siswa pada siklus II lebih baik dari pada siklus I, meski tidak ada perubahan aktivitas individual seperti menulis dan membaca terjadi pada siklus II, namun aktivitas kerja mengalami kenaikan sedikit. Ketergantungan siswa pada guru menurun dengan turunnya aktivitas bertanya pada guru diimbangi dengan naiknya ketergantungan positif antar siswa dengan naiknya aktivitas bertanya sesama siswa. Kesimpulan ini diperkuat dengan temuan bahwa aktivitas yang tidak relevan dengan KBM pada siklu II menyusut dari siklus I. 
Merujuk pada gambar dapat dilihat bahwa nilai rata-rata sebelum penerapan pembelajaran kooperatif tipe STAD yaitu berupa nilai pretes adalah 47,3 dengan ketuntasan belajar yang dicapai $0 \%$, setelah penerapan pembelajaran kooperatif tipe STAD nilai siswa mengalami peningkatan. Berdasarkan hasil tes pada siklus I, nilai rata-rata hasil belajar yang dicapai siswa adalah 73,3 dengan persentasi 50\%, untuk nilai rata-rata hasil belajar dan persentasi ketuntasan klasikal yang dicapai belum mencapai indikator keberhasilan yang ditetapkan karena masih banyak siswa memperoleh nilai yang di bawah kriteria ketuntasan minimal.

Setelah dilaksanakan siklus II, maka hasil belajar siswa menurut formatif II adalah rata-rata 84 dengan ketuntasan klasikal mencapai 90\%. Karena nilai rata-rata di atas KKM sebesar 70 dan ketuntasan klasikal telah mencapai $85 \%$. Maka tindakan siklus II dapat dikatakan berhasil meningkatkan hasil belajar siswa sampai pada kriteria ketuntasan yang ditetapkan.

Kegagalan mencapai ketuntasan belajar pada siklus I, diakibatkan beberapa kekurangan, yaitu:

- Dari gambaran pembelajaran, guru sudah menjelaskan materi pembelajaran tetapi belum memberikan contoh-contoh yang mempermudah siswa.

- Guru juga tidak meninggikan suara saat siswa bertanya hal-hal yang tidak terlalu penting sehingga siswa menjadi takut memberikan tanggapan pada langkah berikutnya sehingga siswa terkesan pasif.

- Beberapa siswa kurang aktif apabila guru menyuruh menyelesaikan soal di depan. Siswa yang maju didominasi oleh siswa yang pandai dalam menyelesaikan masalah.

- LKS dikerjakan kurang optimal karena guru tidak memberitahukan kepada siswa pada pertemuan sebelumnya bahwa akan diberikan LKS pada setiap pertemuan.

- Siswa belum memahami penjelasan guru, sehingga guru dan peneliti harus berkeliling untuk mengetahui pemahaman siswa.

- Ketika mengerjakan latihan soal, masih ada siswa yang berbicara sendiri dengan temannya.

- Penggunaan media dan alat peraga yang belum maksimal.

Pelaksanaan kegiatan belajar mengajar pada siklus I ini masih terdapat kekurangan, sehingga perlu adanya revisi untuk dilakukan pada siklus berikutnya.

- Untuk mempermudah siswa maka guru akan memberikan contohcontoh terlebih dahulu tanpa menjelaskan sehingga muncul suatu permasalahan dan siswa berkeinginan memecahkannya. Prosesnya dibalik dengan menginduksi contoh-contoh menjadi defenisi bukan mendefenisikan begitu saja.

- Guru akan memperbaiki keterampilan bertanya dan memberikan jawaban sehingga tidak membuat siswa takut memberikan tanggapan.

- Guru menampilkan media yang memudahkan siswa melihat untuk membantu siswa memahami materi pelajaran.

- Guru memberikan nilai plus (tambahan) untuk siswa yang dapat menjawab soal yang diberikan guru dengan benar. 
- Latihan soal yang dibahas merupakan latihan soal yang tidak dapat dikerjakan oleh siswa dan latihan soal ditambah dengan memberikan pekerjaan rumah.

- Guru memberitahukan untuk mengulang materi sebelumnya dan mempelajari materi berikutnya, karena setiap pertemuan akan diberikan LKS.

Pembelajaran yang diterapkan pada siklus II sama seperti pada siklus I, yaitu penerapan pembelajaran tipe STAD pada mata pelajaran IPA. Tahapan pembelajaran juga masih sama yaitu dengan menggunakan tiga tahapan sebagai berikut: tahap awal (persiapan), tahap inti (pelaksanaan), dan tahap akhir (penutup).

Selama pengamatan terhadap kegiatan siswa siklus II (aktivitas siswa), penilaian terhadap tes hasil belajar (ranah kognitif), dan dokumentasi terhadap pelaksanaan penerapan pembelajaran kooperatif tipe STAD siklus II, meski masih terlihat hal-hal yang harus diadakan perbaikan, namun secara keseluruhan tahapan pembelajaran sudah berlangsung cukup baik. Kerena keterbatasan waktu dan biaya maka penelitian ini direncanakan dalam dua siklus saja. Hasil belajar siswa sudah menunjukkan peningkatan dan semua siswa dikatakan tuntas. Secara keseluruhan semua aspek dalam hasil belajar mengalami peningkatan dari siklus I ke siklus II. Karena proses pelaksanaan pada siklus I dan siklus II telah dapat mencapai hasil dari pembelajaran yang diharapkan dan telah dapat menjawab rumusan masalah pada penelitian ini, maka tidak diadakan siklus selanjutnya.

\section{KESIMPULAN}

Adapun kesimpulan dari penerapan model kooperatif tipe STAD selama kegiatan belajar mengajar IPA di kelas III-B SD Negeri No. 053975 Stabat Lama T.A 2015/2016 sebagai berikut:

1. a. Data aktivitas siswa rata-rata menurut pengamatan pengamat pada siklus I antara lain menulis dan membaca $51 \%$, bekerja $21 \%$, bertanya sesama teman $3 \%$, bertanya kepada guru 5\%, dan yang tidak relevan dengan KBM $21 \%$.

b. Data aktivitas siswa rata-rata menurut pengamatan pada siklus II antara lain menulis dan membaca $29 \%$, bekerja $42 \%$, bertanya sesama teman $16 \%$, bertanya kepada guru $12 \%$, dan yang tidak relevan dengan KBM 3\%. Sehingga terjadi perbaikan aktivitas belajar siswa selama dua siklus.

2. Hasil belajar siswa dengan menerapkan model pembelajaran kooperatif tipe STAD pada formatif I dan formatif II menunjukkan ratarata 73,3 dan 84 , dari data tersebut menunjukkan tuntas sesuai dengan KKM dengan ketuntasan klasikal $50 \%$ dan $90 \%$ atau ketuntasan klasikal tercapai pada siklus II. Sehingga terjadi peningkatan hasil belajar dari siklus I ke siklus II.

\section{DAFTAR RUJUKAN}

Arniah. (2016). Efetktifitas Model Pembelajaran Kooperatif Tipe STAD (Student Team Achievement Division) Dalam Upaya Peningkatan Hasil Belajar Siswa Pada Mata Pelajaran IPA Di Kelas III-B SD Negeri No. 053975 Stabat Lama T.A 2015/2016. (PTK Karangan Sendiri). 
Djamarah, S dan Zain, A. (2006). Strategi Belajar Mengajar. Jakarta: Rineka Cipta.

Dwi, Suhartanti. (2010). Ilmu Pengetahuan Alam Untuk SD Kelas 3. Jakarta: Pusat Perbukuan, Kementertian Penddidikan Nasional,

Sani, R.A. dan Sudiran, (2012), Meningkatkan Profesionalisme Guru Melalui Penelitian Tindakan Kelas, Citapustaka Media Perintis, Bandung.

Sanjaya, W., (2009), Strategi Pembelajaran Berorientasi Standar Proses Pendidikan, Penerbit Kencana, Jakarta.

Slameto. (2003). Belajar dan FaktorFaktor yang Mempengaruhinya. Jakarta : PT Rineka Cipta.

Sudjana, (2005), Metode Statistika, Penerbit Bumi Aksara, Jakarta. 